\title{
INFECTION RATE BY Toxoplasma gondii IN FREE- RANGE AND BROILER CHICKENS IN THE STATES OF RIO GRANDE DO NORTE AND PARAÍBA, BRAZIL
}

\section{Maria Cecilia Farias dos Santos ${ }^{1}$, Ramayana Morais de Medeiros Brito ${ }^{1,3}$, Ricardo Wagner de Almeida Vitor ${ }^{2}$, and Valter Ferreira de Andrade-Neto ${ }^{1}$}

\section{ABSTRACT}

Toxoplasmosis is a zoonosis caused by Toxoplasma gondii, a protozoan that has a cosmopolitan geographic distribution and low specificity for intermediate hosts. Domestic chickens are among the most important hosts in toxoplasmosis epidemiology, since they are potential sources of infection for humans, in addition to indicating environmental contamination by protozoa. In this work, we studied the prevalence of $T$. gondii infection in chickens in different breeding systems from distinct mesoregions of Rio Grande do Norte and Paraiba States: broiler chickens from commercial farms and free-range chickens from small farms. Indirect fluorescent antibody test (IFAT) and ELISA techniques were used for detecting specific antibodies in blood samples from the birds. There were no seropositive samples among the broilers tested, indicating that intensive management limited the chances of infection for these animals. Among the free-range chickens, the frequency of IgG anti-T. gondii detected by IFAT and ELISA were $37.9 \%$ and $40.4 \%$ respectively. Among the seropositive samples by IFAT, $33(27.1 \%)$ were positive at a dilution of $1: 16$; in 1:32, $31(25.4 \%)$; in $1: 64,24(19.7 \%) ; 15(12.3 \%)$ in $1: 128$, and 19 presented titers greater than or equal to $1: 256(15.6 \%)$. The substantial concordance observed between IFAT and ELISA signifies these methods are effective methodologies for the diagnosis of avian toxoplasmosis. The high prevalence of specific antibodies among poultry in the studied region highlights the potential risk of $T$. gondii transmission to humans through consumption of infected meat.

KEY WORDS: Toxoplasma gondii; chicken infection; toxoplasmosis transmission; seroprevalence.

\footnotetext{
1. Federal University of Rio Grande do Norte, Biosciences Center, Department of Microbiology and Parasitology, Natal, Rio Grande do Norte, Brazil.

2. Federal University of Minas Gerais, Institute of Biological Sciences, Department of Parasitology, Belo Horizonte, Minas Gerais, Brazil.

3. Graduate Program in Parasitary Biology, Departament of Microbiology and Parasitology, Federal University of Rio Grande do Norte, Natal, Rio Grande do Norte, Brazil.
}

Maria Cecília Farias dos Santos - https://orcid.org/0000-0002-9052-5761; Ramayana Morais de Medeiros Brito: Orcid.org/00000003-0611-6859; Ricardo Wagner de Almeida Vitor: Orcid.org/0000-0002-8599-0474; Valter Ferreira de Andrade Neto: Orcid. org/0000-0002-9986-0865

Corresponding author: Valter Ferreira de Andrade-Neto. Department of Microbiology and Parasitology, Biosciences Center, Federal University of Rio Grande do Norte, Av. Senador Salgado Filho 3000, CEP 59078-970, Natal, Rio Grande do Norte, Brazil. E-mail:vfan.aneto@gmail.com and/or aneto@cb.ufrn.br 


\section{INTRODUCTION}

Toxoplasmosis is a zoonosis caused by Toxoplasma gondii, an obligate intracellular parasite from the Alveolata group (Adl et al., 2012) causing severe symptoms in congenitally infected newborns and in immunosuppressed individuals (Furtado et al., 2011; McAuley, 2014). Over the past 50 years, The Americas have been responsible for $73.5 \%$ of human toxoplasmosis outbreaks with Brazil accounting for $35.3 \%$ of the published outbreaks. In addition, the source of infection was mainly consumption of contaminated meat and its derivatives $(47.1 \%)$ followed by ingestion of oocysts (44.1\%) (Pinto-Ferreira et al., 2019). Close contact with domestic animals plays an important role in the epidemiology of toxoplasmosis an indicator of environmental contamination with $T$. gondii oocysts acting as potential sources of infection (Shapiro et al., 2019).

An important aspect related to the prevalence of this protozoan infection in birds is the role these animals play in transmitting $T$. gondii to carnivores through the consumption of infected meat (Nardoni et al., 2019; Khan et al., 2020). Almost twenty years ago, Literak \& Hejlicek (1993) had already drawn attention to the fact that chickens from small farms could contain T. gondii tissue cysts, risking human infection. Two years later, Camargo et al. (1995) observed that the proportion of individuals who had contact with chickens raised in their backyards was statistically higher in the group with reactive serology than in the group with non-reactive serology, suggesting a relationship between contact with domestic chickens and the increased chances of acquiring infection. Thus, domestic chickens can be reservoirs, playing a crucial role in the epidemiology of toxoplasmosis, as a source of infection to humans (Dubey, 2010).

Chickens reared intensively present low infection rates due to correct management, restriction and hygiene procedures that reduce or even prevent contact with T. gondii infection sources (Dubey, 2010; Khan et al., 2020). Recently, consumers have become more concerned about animal welfare, leading to an inflated demand for production systems that reduce animal suffering, such as free-range and organic systems. These methods have spread rapidly throughout the world (Cobanoglu et al. 2014), however, evidence suggests that the health of animals raised on free and organic farms is not always better than that observed in animals raised in conventional livestock production systems (Millar et al., 2012; Tomza-Marciniak et al., 2014; Ferdushy et al., 2016). Seroprevalence analysis of T. gondii infection in birds revealed a higher prevalence in free-range chickens than in broilers (Khan et al., 2020). Previous studies conducted in Brazil reported T. gondii infection prevalence ranging from $27.9 \%$ up to $48.9 \%$ in free-range chickens (Sá et al., 2017; Braz et al., 2020; Silva et al., 2020). 
Many techniques are utilized for the diagnosis of avian $T$. gondii infection, mainly based on DNA detection and investigation of antibodies against the parasite through serological testing (Liu et al., 2015; Nunes et al.; 2015; Khan et al., 2020). The importance of this diagnosis implies the adoption of specific criteria in the choice of an efficient method, capable of providing reliable results. Regarding animal infection, indirect fluorescent antibody test (IFAT), modified agglutination test (MAT), indirect haemagglutination assay (IHA) and enzyme-linked immunosorbent assay (ELISA) are the most used techniques for routine diagnosis and serological surveys (Casartelli-Alves et al., 2014; Dard et al., 2016; Schares et al., 2018; Sharma et al., 2019). However, the lack of standardized guidelines and inexistence of a gold standard for the diagnosis of avian toxoplasmosis hamper calculation of parameters such as sensitivity and specificity of serological techniques employed to obtain accurate results. Therefore, the main purpose of this study was to determine the occurrence of anti- $T$. gondii antibodies in chickens raised under different systems (free-range and confined chickens) and compare the efficiency of ELISA and IFAT as diagnostic tools.

\section{MATERIAL AND METHODS}

\section{Study design}

Five hundred twenty two chickens were evaluated, 322 freerange chickens (of which 76 were young chickens from the East Potiguar Mesoregions) and 200 confined broilers. The animals were randomly selected and the sampling locations were East and West Potiguar Mesoregions in the State of Rio Grande do Norte, and Agreste (semi-arid transition region) and Borborema (plateau area) regions in the State of Paraíba, Northeast of Brazil. The samples were collected from November 2018 to November 2019. This work is part of a research project on animal toxoplasmosis carried out over the last eight years.

Free-range chicken samples were collected from 15 rural properties in the following municipalities: Macaíba, Martins and Felipe Guerra, in the State of Rio Grande do Norte; and Pocinhos, Gado Bravo, Boqueirão, Massaranduba, Queimadas and Campina Grande, in the State of Paraíba. Confined chicken samples were collected from three intensive breeding (broiler) commercial farms in the State of Paraíba in the municipalities of Pocinhos, Soledade and Puxinanã (Figure 1). The properties selected for the study were based on nonprobabilistic sampling for convenience, in view of the lack of registration lists of the flocks of domestic chickens bred in those States. 


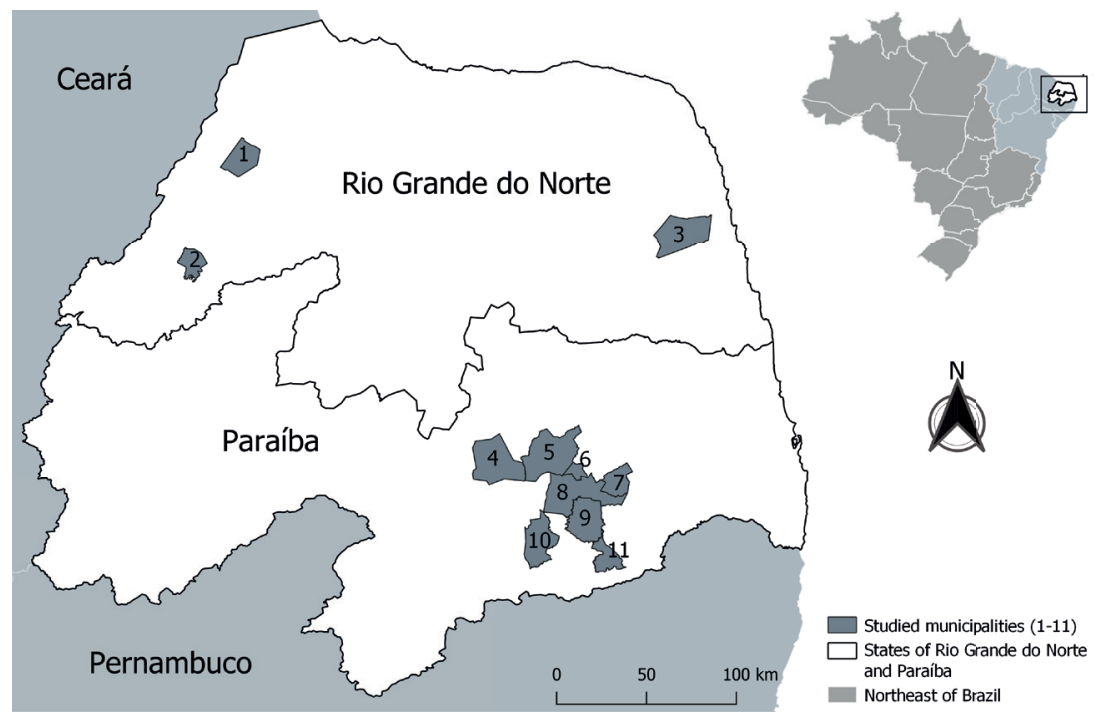

Figure 1. Map of Rio Grande do Norte and Paraíba states, in the Northeast of Brazil, evidencing the municipalities where the samples were collected.

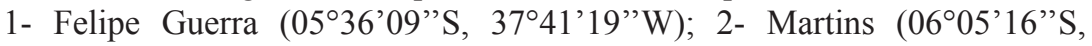

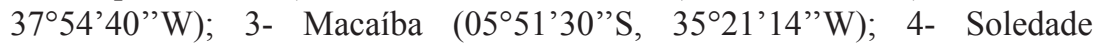
$\left(07^{\circ} 03^{\prime} 26^{\prime \prime} \mathrm{S}, \quad 36^{\circ} 21^{\prime} 46^{\prime \prime} \mathrm{W}\right)$; 5- Pocinhos $\left(07^{\circ} 04^{\prime} 36^{\prime \prime} \mathrm{S}, \quad 36^{\circ} 03^{\prime} 40^{\prime \prime} \mathrm{W}\right)$; 6- Puxinanã $\left(07^{\circ} 09^{\prime} 40^{\prime \prime} \mathrm{S}, 35^{\circ} 57^{\prime} 38^{\prime \prime} \mathrm{W}\right)$; 7- Massaranduba $\left(07^{\circ} 12^{\prime} 01^{\prime \prime} \mathrm{S}\right.$,

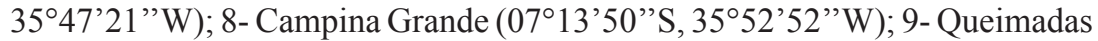
$\left(07^{\circ} 21^{\prime} 30^{\prime \prime} \mathrm{S}, 35^{\circ} 53^{\prime} 54^{\prime \prime} \mathrm{W}\right)$; 10- Boqueirão (07²8'54"'S, 3608'06”'W); 11 -

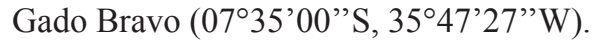

\section{Chickens and serum samples}

All procedures used in this study were authorized for publication following approval by the Research Ethics Committee of the Federal University of Rio Grande do Norte (CEUA/UFRN 76/2015).

Blood samples were obtained by puncturing the brachial vein of the birds (approximately $0.8 \mathrm{~mL} / \mathrm{bird}$ ) and kept at room temperature for clot retraction. Sera were transported in containers to the Laboratory of Malaria Biology and Toxoplasmosis, Biosciences Center of the Federal University of Rio Grande do Norte. The serum samples were obtained by centrifugation at $2.500 \mathrm{~g}$ for 15 minutes, aliquoted into Eppendorf microtubes and stored at $-20{ }^{\circ} \mathrm{C}$ until serological tests were performed. 
IFAT was performed according to the method described by Chiari et al. (1987), with modifications. The antigen used here was prepared with tachyzoites of $T$. gondii RH strain, obtained by peritoneal cavity wash with phosphatebuffered saline (PBS, pH 7.2) of infected Swiss mice. The suspension obtained was transferred to labeled slides and the formalized tachyzoites fixed through drying at room temperature. The prepared slides were stored in appropriate boxes and kept at $-20{ }^{\circ} \mathrm{C}$ until use.

For IFAT, sera were diluted from 1:16 to 1:256 in phosphate buffered saline (PBS) pH 7.2 to detect specific IgG antibodies. The diluted samples were transferred to previously prepared antigen-sensitized slides, in duplicate. One positive and two negative control sera were used from $T$. gondii infected and non-infected chickens respectively. The slides were coverslipped and examined through a fluorescent microscope (Olympus IX70-FLA; excitation filter BP460-490; barrier filter BA515IF). The samples were considered reactive when the tachyzoites exhibited complete fluorescence. Sera with titers equal to or greater than 1:16 were considered positive, according to Chumpolbanchorn et al. (2009).

Serological frequency using ELISA assay

ELISA was performed according to the technique described by Voller et al. (1976), with modifications described by Clementino et al. (2007). The antigen used here was obtained, as previously described (Clementino et al., 2007), in a concentration of $0.05 \mu \mathrm{g} /$ well. For the preparation of the antigen, peritoneal exudate was collected from mice, previously inoculated with the RH strain of T. gondii. The material was centrifuged twice in PBS pH 7.2 and $10 \mathrm{~mL}$ of PBS pH 7.2 were added to the remaining pellet. Then the parasites were counted in a Neubauer chamber and the final concentration adjusted to $1 \times 10^{9}$ tachyzoites $/ \mathrm{mL}$. This suspension was processed by ultrasound in five cycles of 40 hertz (in an ice bath), for one minute with one-minute intervals between each cycle. The breaking of the parasites was monitored under an optical microscope. After sonication, the material was centrifuged at 15.000 $\mathrm{g}$ at $4^{\circ} \mathrm{C}$ for 30 minutes. The supernatant was stored at $-20^{\circ} \mathrm{C}$ until use. The protein concentration was determined by the Lowry method (1951). Nine control sera were used: three positive and six negative chickens previously tested by IFAT and/or ELISA. Sera were diluted at 1:100 and the conjugate (anti-chicken IgG peroxidase antibody) (Sigma Chemical Company) diluted at 1:4000 followed by the addition of o-phenylenediamine in citric acid solution plus $\mathrm{H}_{2} \mathrm{O}_{2}$. Absorbance was read at $492 \mathrm{~nm}$ using an ELISA reader (BIO-RAD Laboratories). 
The cut-off point for the ELISA was the mean absorbance of six $T$. gondii negative chicken serum samples plus three standard deviations tested on each plate. The average of the sera tested in duplicate was divided by the value of the plate cut-off point, in order to determine the reactivity index (RI). The sera with RI values equal to or greater than 1 were considered positive (Altcheh et al., 2006). To ensure the reproducibility of the test and the reliability of the results, ELISA was repeated at least three times.

\section{Statistical analysis}

For data analysis, the frequency of positive/negative samples and the estimated prevalence of $T$. gondii infection were evaluated for the serological techniques used with estimates of $95 \%$ confidence intervals (CI). The correspondence analysis was performed to evaluate the correlation between the number of positive and negative samples by the two serological techniques. In order to compare IFAT and ELISA, the McNemar test was used to evaluate the equality between the positivity proportions generated by each of the techniques.

The concordance between tests was verified by the Kappa index, where levels of comparison to assess the index were: $>0.81$ (almost perfect); 0.61 to 0.8 (substantial concordance); 0.41 to 0.6 (moderate concordance); 0.21 to 0.4 (reasonable concordance); 0 to 0.2 (weak concordance); 0 (poor concordance) (Landis \& Koch, 1977); the determination of concordance values, co-positivity (PPV - Positive Predictive Value) and co-negativity (NPV - Negative Predictive Value), and prevalence were made through a $2 \times 2$ contingency table. The basis of this approach is that the correlation between the methods is evidence of validity, while the non-concordance suggests that the tests are not reliable (Watson \& Petrie, 2010).

The Chi-squared test and multifactorial ANOVA analyses were performed to compare seropositivity and the variables related to the characteristics of the animals, using the Minitab 15 software. P values $<0.05$ were considered significant.

\section{RESULTS}

The distribution of the positive samples according to the municipalities are in Table 1. The age distribution was $76(23.6 \%)$ young animals and 246 (76.4\%) adult animals. From the total of adult animals, $22(8.9 \%)$ birds were male and 224 (91.1\%) female. 


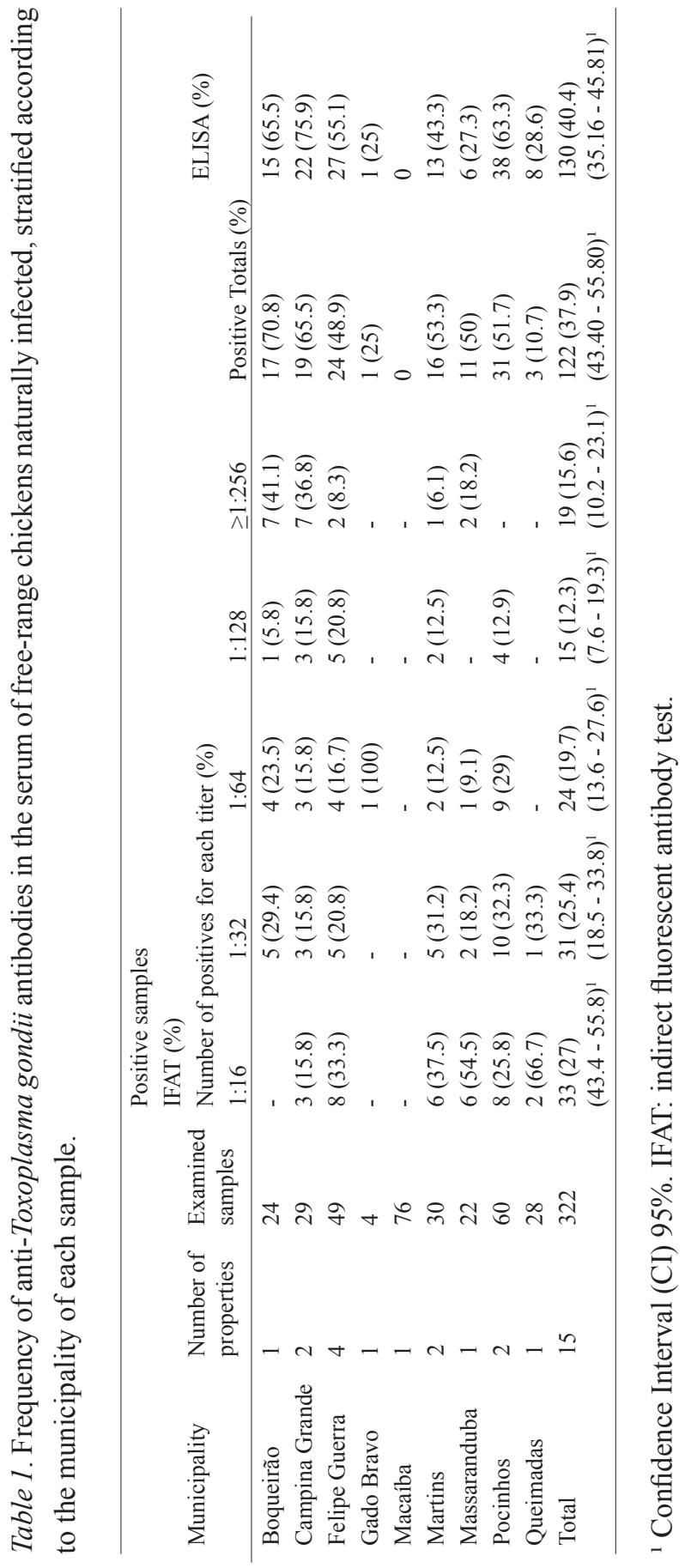


From the total number of free-range chickens analyzed, 155 were reactive (48.1\%, CI 95\% 42.56-53.74) and 167 (51.9\%, CI 95\% 46.25-57.43) non-reactive in at least one of the two methodologies studied. Analyzing each technique individually, 122 samples $(37.9 \%$, 95\% CI 32.76-43.30) were reactive for the presence of anti-T. gondii antibodies by IFAT and 130 samples were reactive by ELISA (40.4\%; 95\% CI: 35.16-45.81) (Table 1). All the 200 samples from confined chickens were non-reactive for anti-T. gondii antibodies in both tests.

In the IFAT titration, the highest number of reactive sera was observed at 1:16 dilution (Table 1). Regarding the ELISA, the animals with positive sera were those with RI values greater than or equal to 1 , and the concentration of the highest number of reactive birds exhibited RI $\geq 1$ and $<2$ (Figure 2).

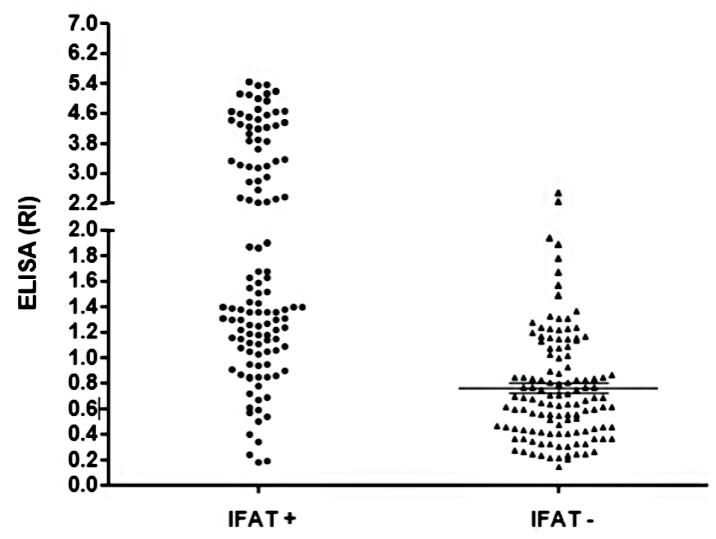

Figure 2. Representative data of the reactivity index (RI) values of each analyzed sample of adult free-range chickens by ELISA, grouped according to the positive or negative results from indirect fluorescent antibody test (IFAT).

The highest values of seropositivity were observed in the municipalities of Campina Grande and Boqueirão, according to the data presented by IFAT and ELISA (Table 1). The proportion of positive farms was $100 \%$ for all regions except East Potiguar, and the region with the highest proportion of positive samples was Borborema with a positivity of $70.8 \%$ and $62.5 \%$ for IFAT and ELISA, respectively (Table 2).

No positive samples were identified in the East Potiguar Mesoregion, therefore excluding the young birds from the analysis of gender and age. When evaluating the seropositivity of these animals according to gender, $40.9 \%$ of the males and $50.4 \%$ of females reacting to T. gondii were detected by IFAT, whereas using ELISA seropositivity was found in 31.8\% and 54.9\%, respectively. However, the Chi-squared test showed significant differences only for ELISA (Table 3). 
According to the McNemar test, there was no significant difference between the positivity ratios between the two serological techniques $\left(\mathrm{X}^{2}=\right.$ 1.1034; $\mathrm{p}=0.2935)$. When IFAT test was compared to ELISA, a co-positivity value of $74.6 \%(\mathrm{PPV}=0.746)$ and co-negativity of $86.9 \%(\mathrm{NPV}=0.869)$ was observed. In this comparison, a prevalence of 37.8\% (CI95\% 32.76-43.30) was noted. Likewise, when comparing ELISA to IFAT, similar results were obtained. The co-positivity analysis revealed a value of 79.5\% (PPV=0.795) and co-negativity of $83.5 \%(\mathrm{NPV}=0.835)$. Here, the prevalence obtained was $40.3 \%$ (CI95\% 35.16-45.81). These comparisons revealed an observed concordance of $82 \%$ and a kappa index of 0.62 , which indicates a substantial concordance between the analyzed methodologies.

Table 2. Frequency of anti-Toxoplasma gondii antibodies in the serum of freerange chickens naturally infected, stratified according to the mesorregion of each sample.

\begin{tabular}{|l|l|l|l|}
\hline Mesoregion & $\begin{array}{l}\text { Examined } \\
\text { samples }\end{array}$ & Positive samples \\
\cline { 3 - 4 } & 79 & IFAT (\%) & ELISA (\%) \\
\hline West Potiguar & 76 & 0 & $40(50.63)$ \\
\hline East Potiguar & $76.63)$ & 0 \\
\hline Agreste Paraibano & 143 & $65(45.45)$ & $75(52.45)$ \\
\hline Borborema & 24 & $17(70.83)$ & $15(62.50)$ \\
\hline Total & 322 & $\begin{array}{l}122(37.88) \\
(32.76-43.30)^{1}\end{array}$ & $\begin{array}{l}130(40.37) \\
(35.16-45.81)^{1}\end{array}$ \\
\hline
\end{tabular}

${ }^{1}$ Confidence Interval (CI) 95\%. IFAT: indirect fluorescent antibody test.

Table 3. Frequency of anti-Toxoplasma gondii antibodies in the serum of freerange chickens naturally infected, stratified according to age and gender of each animal.

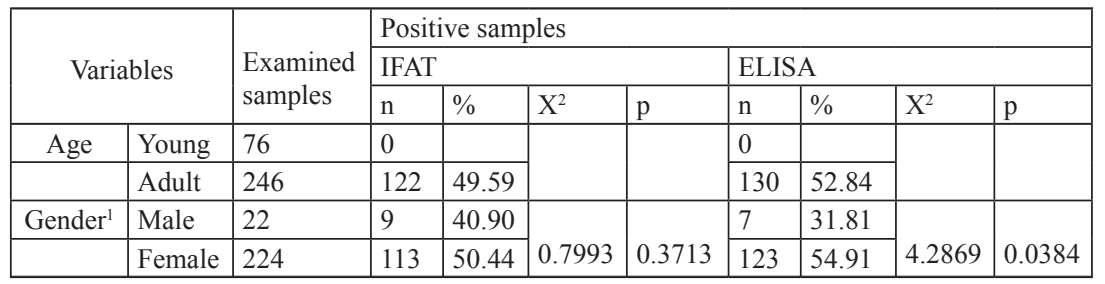

${ }^{1}$ Confidence Interval (CI) 95\%; evaluating only 246 adult animals. IFAT: indirect fluorescent antibody test. 


\section{DISCUSSION}

In the present study, a high seroprelavence of Toxoplasma gondii infection was detected in adult free-range chickens in the states of Rio Grande do Norte and Paraíba, Northeast of Brazil, showing that $48.1 \%$ of the analyzed birds were reactive for anti-T. gondii specific antibodies in at least one of the two applied methodologies. The prevalence of $T$. gondii infection in adult birds can be the result of longer exposure to the parasite when compared to young birds. This fact is in accordance with data shown by More et al. (2012), which presented a difference of infection positivity between young and adult chickens, varying from $3 \%$ to $50 \%$, respectively, on six farms in Argentina. On the other hand, it is important to highlight that different factors may also be related to the seronegativity of young free-range chickens, such as management procedures and less exposure to risk factors. In addition, in the present study, the population of young animals surveyed originated from only one rural property, in the East Potiguar Mesoregion, totaling the entire sample. There is a possibility that animals from the same herd or flock of birds, react homogeneously when they are kept in similar conditions, while the dispersion of toxoplasmosis can vary in animals of different origins (Chiari et al., 1987).

In general, looking at the adult bird population, the seroprevalence found here was similar to that observed by other researchers also studying free-range chickens (Brandão et al., 2006; Dubey et al., 2002; Dubey et al., 2003a; Dubey et al., 2007a; De Oliveira et al., 2009; Dubey et al., 2010). As in Brazil, reports in the world literature on the research of T. gondii antibodies in chickens have differing prevalences (Dubey et al., 2003b; Dubey et al., 2003c; Dubey et al., 2004; Dubey et al., 2005; Dubey et al., 2006a; Dubey et al., 2006b; Dubey et al., 2006c; Dubey et al., 2007b; Dubey et al., 2008), which may reflect the varying levels of infectivity in the studied ecosystems or variations in the sensitivity of applied techniques (Garcia et al., 2000).

Regarding the gender of the free-range chickens evaluated in this work, the sample consisted of 224 females and 22 males, considering only adult birds. This difference in gender proportion is justified, as on small farms the sex ratio of males is usually lower, due to reproductive aspects and the welfare of the birds. Although the statistical analysis of the data showed a significant difference between the prevalence of anti- $T$. gondii antibodies in males and females only by ELISA, the gender role in this proportion can be questionable, due to the low number of males evaluated. Ueno et al. (2009) verified the prevalence of $T$. gondii infection in sheep and argued that the divergence of results between genders does not obey a coherent biological explanation and, therefore, this fact would be due to chance. 
Analyzing the reactivity index (RI) of the samples tested by ELISA, the distribution of positive samples was concentrated between RI values $\geq 1$ and $<2$. On none of the properties did the chickens have excessively high titers, as observed in previous studies (Holsback et al., 2012; Vieira et al., 2018). Through experimental infection of domestic chickens, a progressive decrease in antibody titers after reaching a peak at 35 days after infection with antibodies still detectable by direct agglutination at 63 days after infection (Galli et al., 2008).

In general, $T$. gondii seropositivity in animals raised for human consumption does not necessarily reflect the risk of infection to humans, due to variations in the organotropism of the parasite in different host species (Dubey \& Jones, 2008; Cenci-Goga et al., 2011). However, cultural eating habits can be considered an infection risk factor. In Brazilian cuisine, the chicken heart is traditionally used in local gastronomy, usually served as a starter or "appetizer", or even in the form of skewers. In such cases, the cooking may not occur homogeneously, favoring the viability of possible tissue cysts present in the bird's cardiac musculature (Dubey et al., 1993; Kaneto et al., 1997), posing a serious infection risk.

Our results demonstrate that the absence of seropositivity among the broilers analyzed highlights the little epidemiological importance of these animals in the transmission of $T$. gondii, indicating that adequate management, in this breeding system, contributes enormously to animal protection. However, the high seropositivity of free-range chickens indicates that the protozoan is widespread in the states of Rio Grande do Norte and Paraíba, indicating that these animals may be bioindicators of environmental contamination by oocysts. Last but not least, the cultural custom in Brazilian cuisine of eating undercooked chicken hearts can be a source of infection for humans, serving as a maintainer of human infection. The concordance observed in the IFAT and ELISA results was considered substantial as well as the seroprevalence noted using both tests; this fact shows the relevance of this study. Finally, these data showed that both techniques are appropriate for carrying out epidemiological surveys of $T$. gondii infection in chickens.

\section{ACKNOWLEDGMENTS}

This work was supported by Conselho Nacional de Desenvolvimento Científico e Tecnológico (CNPq), Coordenação de Aperfeiçoamento de Pessoal de Nível Superior (CAPES), Fundação de Amparo à Pesquisa do Estado de Minas Gerais (FAPEMIG), Federal University of Rio Grande do Norte (UFRN) and Federal University of Minas Gerais (UFMG), Brazil. VFAN (Process number 306036/2019-3) and RWAV (Process number 304815/2017-9) are CNPq Research Productivity Scholarship. The authors would like to thank the farm owners and poultry industries for their support and logistics. To Rosalida Estevan Nazar Lopes, for her technical assistance and to Wagner Skellington for his contribution in making the maps of the studied regions. 


\section{CONFLICT OF INTEREST}

The authors declare no conflicts of interest.

\section{REFERENCES}

1. Adl SM, Simpson AGB, Lane CE, Lukes J, Bass D, Bowser SS, Brown MW, Burki F, Dunthorn M, Hampl V, Heiss A, Hoppenrath M, Lara E, Gall LL, Lynn DH, McManus H, Mitchell EAD, Mozley-Stanridge SE, Parfrey LW, Pawlowski J, Rueckert S, Shadwick L, Schoch CL, Smirnov A, Spiegel FW. The revised classification of eukaryotes. J Eukaryot Microbiol 59: 429-493, 2012.

2. Altcheh J, Diaz NS, Pepe CM, Martin V, Nigro M, Freilij H, Angel SO. Kinetic analysis of the humoral immune response against 3 Toxoplasma gondii-recombinant proteins in infants with suspected congenital toxoplasmosis. Diagn Microbiol Infect Dis 56: 161-165, 2006.

3. Brandão GP, Ferreira AM, Melo MN, Vitor RWA. Characterization of Toxoplasma gondii from domestic animals from Minas Gerais, Brazil. Parasite 13: 143-149, 2006.

4. Braz BMA, Feitosa BCO, Romão EA, da Silva EM, Pinheiro Júnior JW, Mota RA, de Azevedo SS, Porto WJN. Cross-sectional survey for toxoplasmosis in free-range chickens (Gallus gallus domesticus) from the Atlantic Forest area in Alagoas state, Northeastern Brazil. Rev Bras Parasitol Vet 29: e014120, 2020.

5. Camargo MCV, Antunes CMF, Chiari CA. Epidemiologia da infecção por Toxoplasma gondii no município de Ribeirão das Neves, MG. I. Importância dos animais domésticos como fonte de infecção do T. gondii para o homem. Rev Soc Bras Med Trop 28: 211-214, 1995.

6. Casartelli-Alves L, Boechat VC, Macedo-Couto R, Ferreira LC, Nicolau JL, Neves LB, Millar PR, Vicente RT, Oliveira RVC, Muniz AG, Bonna ICF, Amendoeira MRR, Silva RC, Langoni H, Schubach TMP, Menezes RC. Sensitivity and specificity of serological tests, histopathology and immunohistochemistry for detection of Toxoplasma gondii infection in domestic chickens. Vet Parasitol 204: 346-351, 2014.

7. Cenci-Goga BT, Rossitto PV, Sechi P, McCrindle CM, Cullor JS. Toxoplasma in animals, food and humans: an old parasite of new concern. Foodborne Pathog Dis 8: 751-762, 2011.

8. Chiari CA, Lima WS, Antunes CMF, Lima JD. Soroepidemiologia da toxoplasmose caprina em Minas Gerais, Brasil. Braz J Vet Anim Sci 39: 587-609, 1987.

9. Chumpolbachorn K, Anankeatikul P, Ratanasak W, Wienggharoen J, Thompson RCA, Sukthana Y. Prevalence of Toxoplasma gondii indirect fluorescent antibodies in naturally- and experimentally-infected chickens (Gallus domesticus) in Thailand. Acta Parasitol 54: 194196, 2009.

10. Clementino MM, Souza MF, Andrade-Neto VF. Seroprevalence and Toxoplasma gondii-IgG avidity in sheep from Lajes, Brazil. Vet Parasitol 146: 199-203, 2007.

11. Cobanoglu F, Kucukyilmaz K, Cinar M, Bozkurt M, Catlu AU, Bintas E. Comparing the profitability of organic and conventional broiler production. Braz J Poult Sci 16: 89-96, 2014.

12. Dard C, Fricker-Hidalgo H, Brenier-Pinchart MP, Pelloux H. Relevance of and new developments in serology for toxoplasmosis. Trends Parasitol 32: 492-506, 2016.

13. De Oliveira LN, Costa-Junior LM, De Melo CF, Ramos Silva JC, Bevilaqua CM, Azevedo SS, Muradian V, Araujo DA, Dubey JP, Gennari SM. Toxoplasma gondii isolated from free-range chickens from the northeast region of Brazil. J Parasitol 95: 235-237, 2009.

14. Dubey JP, Ruff MD, Camargo ME, Khen SK, Wilkins GL, Kwok OC, Thulliez P. Serologic and parasitologic responses of domestic chickens after oral inoculation with Toxoplasma gondii oocysts. Am J Vet Res 54: 1668-1672, 1993. 
15. Dubey JP, Graham DH, Blackston CR, Lehmann T, Gennari SM, Ragozo AMA, Nishi SM, Shen SK, Kwok OCH, Hill DE. Biological and genetic characterization of Toxoplasma gondii isolates from chickens (Gallus domesticus) from São Paulo, Brazil: unexpected findings. Int $J$ Parasitol 32: 99-105, 2002.

16. Dubey JP, Navarro IT, Graham DH, Dahl E, Freire RL, Prudencio LB, Sreekumar C, Vianna MC, Lehmann T. Characterization of Toxoplasma gondii isolates from free-range chickens from Paraná, Brazil. Vet Parasitol 117: 229-234, 2003 a.

17. Dubey JP, Graham DH, Dahl E, El-Ghaysh A, Sreekumar C, Kwok OCH, Shen SK, Lehmann T. Isolation and molecular characterization of Toxoplasma gondii from chickens and ducks from Egypt. Vet Parasitol 114: 89-95, 2003b

18. Dubey JP, Venturini MC, Venturini L, Piscopo M, Graham DH, Dahl E, Sreekumar C, Vianna MC, Lehmann T. Isolation and genotyping of Toxoplasma gondii from free-range chickens from Argentina. J Parasitol 89: 1063-1064, 2003c.

19. Dubey JP, Levy MZ, Sreekumar C, Kwok OC, Shen SK, Dahl E, Thulliez P, Lehmann T. Tissue distribution and molecular characterization of chickens isolates of Toxoplasma gondii from Peru. J Parasitol 90: 1015-1018, 2004.

20. Dubey JP, Karhemere S, Dahl C, Sreekumar C, Diabaté A, Dabiré KR, Vianna MCB, Kwok $\mathrm{OCH}$, Lehmann T. First biologic and genetic characterization of Toxoplasma gondii isolates from chickens from Africa (Democratic Republic of Congo, Mali, Burkina Faso and Kenya). $J$ Parasitol 91: 69-72, 2005.

21. Dubey JP, Gennari SM, Labruna MB, Camargo LM, Vianna MC, Marcet PL, Lehmann T. Characterization of Toxoplasma gondii isolates in free-range chickens from Amazon, Brazil. $J$ Parasitol 92: 36-40, 2006a.

22. Dubey JP, Patitucci AN, Su C, Sundar N, Kwok OCH, Shen SK. Characterization of Toxoplasma gondii isolates in free-range chickens from Chile, South America. Vet Parasitol 140: 76-82, 2006b.

23. Dubey JP, Sundar N, Pineda N, Kyvsgaard NC, Luna LA, Rimbaud E, Oliveira JB, Kwok $\mathrm{OCH}$, Qi Y, Su C. Biologic and genetic characteristics of Toxoplasma gondii isolates in freerange chickens in Nicaragua, Central America. Vet Res 142: 47-53, $2006 \mathrm{c}$.

24. Dubey JP, Applewhait L, Sundar N, Velmurugan GV, Bandini LA, Kwok OCH, Hill R, Su C. Molecular and biological characterization of Toxoplasma gondii isolates from free-range chickens from Guyana, South America identified several unique and common parasite genotypes. Parasitology 134: 1559-1566, 2007a.

25. Dubey JP, Sundar N, Gennari SM, Minervino AH, Farias NA, Ruas JL, Dos Santos TR, Cavalcante GT, Kwok OC, Su C. Biologic and genetic comparison of Toxoplasma gondii isolates in free-range chickens from the northern Para state and the southern state of Rio Grande do Sul, Brazil revealed highly diverse and distinct parasite populations. Vet Parasitol 143: 182-188, $2007 \mathrm{~b}$.

26. Dubey JP, Huong LT, Lawson BW, Subekti DT, Tassi P, Cabaj W, Sundar N, Velmurugan GV, Kwok OC, Su C. Seroprevalence and isolation of Toxoplasma gondii from free-range chickens in Ghana, Indonesia, Italy, Poland and Vietnam. J Parasitol 94: 68-71, 2008.

27. Dubey JP, Jones JL. Toxoplasma gondii infection in humans and animals in the United States. Int J Parasitol 38: 1257-1278, 2008.

28. Dubey JP. Toxoplasma gondii infections in chickens (Gallus domesticus): prevalence, clinical disease, diagnosis and public health significance. Zoo Public Health 57: 60-73, 2010.

29. Dubey JP, Rajendran C, Costa DG, Ferreira LR, Kwok OC, Su C, Marvulo MF, Alves LC, Mora RA, Silva JC. New Toxoplasma gondii genotypes isolated from free-range chickens from the Fernando de Noronha, Brazil: unexpected findings. J Parasitol 96: 709-712, 2010. 
30. Ferdushy T, Hasan MT, Kadir AKMG. Cross sectional epidemiological investigation on the prevalence of gastrintestinal helminths in free range chickens in Narsingi district, Bangladesh. J Parasitic Dis 40: 818-822, 2016.

31. Furtado JM, Smith JR, Belfort-Jr R, Gattey D, Winthrop KL. Toxoplasmosis: A global threat. J Global Infect Dis 3: 281-284, 2011.

32. Galli S, Belinato FC, Lucas TM, Da Silva RC, Langoni H, Da Silva AV. Experimental infection of domestic chickens (Gallus gallus) with genetically distinct strains of Toxoplasma gondii. $J$ Vet Zootec 15: 542-550, 2008.

33. Garcia, JL, Navarro L, Olivei IT, Ogawa RC, Marana ERM. Seroprevalence of Toxoplasma gondii in backyard chicken (Gallus gallus domesticus) from rural properties in North region of Paraná State, Brazil. Cienc Rural 30: 123-127, 2000.

34. Holsback L, Pena HFJ, Ragozo A, Lopes EG, Gennari SM, Soares RM. Serologic and molecular diagnosic and bioassay in mice for detection of Toxoplasma gondii in free range chickens from Pantanal of Mato Grosso do Sul. Braz J Vet Parasitol 38: 721-726, 2012.

35. Kaneto CN, Costa AJ, Paulillo AC, Moraes F, Murakami TO, Meirelles MV. Experimental toxoplasmosis in broiler chicks. Vet Parasitol 69: 203-210, 1997.

36. Khan MB, Khan S, Rafiq K, Khan SN, Attaullah S, Ali I. Molecular identification of Toxoplasma gondii in domesticated and broiler chickens (Gallus domesticus) that possibly augment the pool of human toxoplasmosis. PlosOne 15: e0232026, 2020.

37. Landis JR, Koch GG. An Application of Hierarchical Kappa-type Statistics in the Assessment of Majority Agreement among Multiple Observers. Biometrics 33: 363-74, 1977.

38. Literak I, Hejlicek K. Incidence of Toxoplasma gondii in population of domestic birds in the Czech Republic. Avian Pathol 22: 275-281, 1993.

39. Liu Q, Wang ZD, Huang SY, Zhu XQ. Diagnosis of toxoplasmosis and typing of Toxoplasma gondii. Parasit Vectors 8: 292, 2015.

40. Lowry OH, Roserbrough NJ, Farr AL, Randall RJ. Protein measurement with the Folin phenol reagent. J Biol Chem 193: 265-275, 1951.

41. McAuley JB. Congenital Toxoplasmosis. J Pediatr Infect Dis Society 3: 30-35, 2014.

42. Millar PR, Alves FMX, Teixeira VQ, Vicente RT, Menezes EM, Sobreiro LG, Peireira VLA, Amendoeira MRR. Occurrence of infection with Toxoplasma gondii and factors associated with transmission in broiler chickens and laying hens in different raising systems. Braz J Vet Res 32: 231-236, 2012.

43. Moré G, Maksimov P, Pardini L, Herrmann DC, Bacigalupe D, Maksimov A, Basso W, Conraths FJ, Schares G, Venturini MC. Toxoplamsa gondii infection in sentinel and free-range chickens from Argentina. Vet Parasitol 184: 116-121, 2012.

44. Nardoni S, Rocchigiani G, Varvaro I, Altomonte I, Ceccherelli R, Mancianti F. Serological and molecular investigation on Toxoplasma gondii infection in wild birds. Pathogens 8: 58, 2019.

45. Nunes ACBT, Silva EMV, Oliveira JA, Yamasaki EM, Kim PCP, Almeida JC, Nunes KB, Mota RA. Application of different techniques to detect Toxoplasma gondii in slaughtered sheep for human consumption. Braz J Vet Parasitol 24: 416-421, 2015.

46. Pinto-Ferreira F, Caldart ET, Pasquali AKS, Mitsuka-Bregano R, Freire RL, Navarro IT. Patterns of transmission and sources of infection in outbreaks of human Toxoplasmosis. Emerg Infect Dis 25: 2177-2182, 2019.

47. Schares G, Koethe M, Bangoura B, Geuthner AC, Randay F, Ludewig M, Maksimov P, Sens M, Bärwald A, Conraths FJ, Villena I, Aubert D, Opsteegh M, Van der Giessen J. Toxoplasma gondii infections in chickens - performance of various antibody detection techniques in serum and meat juice relative to bioassay and DNA detection methods. Int J Parasitol 48: 751-762, 2018. 
48. Shapiro K, Bahia-Oliveira L, Dixon B, Dumetre A, Wit LA, VanWormer E, Villena I. Environmental transmission of Toxoplasma gondii: Oocysts in water, soil and food. Food Waterborne Parasitol 12: e00049, 2019.

49. Sharma R, Parker S, Al-Adhami B, Bachand N, Jenkins E. Comparison of tissue (heart vs. brain) and serological tests (MAT, ELISA and IFAT) for detection of Toxoplasma gondii in naturally infected wolverines (Gulo gulo) from the Yukon, Canada. Food Waterborne Parasitol 12: e00146, 2019.

50. Sá SG, Ribeiro-Andrade M, Silva LTR, Souza Neto OL, Lima DCV, Pedrosa CM, Bezerra MJG, Mota RA. Risk factors associated with Toxoplasma gondii infection in free-range chickens in the semiarid region of Brazil. Rev Bras Parasitol Vet 26: 221-225, 2017

51. Silva ACS, Barros LD, Barros VMC, Alcântara AM, Andrade MR, Garcia JL, Mota RA, Porto WJN. Occurrence of atypical and new genotypes of Toxoplasma gondii in free-range chickens intended for human consumption in Brazil. Acta Parasitol 65: 774-778, 2020.

52. Tomza-Marciniak A, Pilarczyk B, Tobianska B, Tarasewicz N. Gastrintestinal parasites of freerange chickens. Ann Parasitol 60: 305-308, 2014.

53. Ueno TEH, Gonçalves VSP, Heinemann MB, Dilli TLB, Akimoto BM, Souza SLP, Gennari SM, Soares RM. Prevalence of Toxoplasma gondii and Neospora caninum infections in sheep from Federal District, central region of Brazil. Trop Anim Health Prod 41: 547-552, 2009.

54. Vieira FEG, Sasse JP, Minutti AF, Miura AC, Barros LD, Cardim ST, Martins TA, Seixas M, Yamamura MI, Su C, Garcia JL. Toxoplasma gondii: prevalence and characterization of new genotypes in free-range chickens from south Brazil. Parasitol Res 117: 681-688, 2018.

55. Voller A, Bidwell DE, Bartlett A. Enzyme immunoassays in diagnostic medicine. Bull World Health Organ 53: 55-65, 1976.

56. Watson PF, Petrie A. Method agreement analysis: a review of correct methodology. Theriogenology 73: 1167-1179, 2010. 